\title{
Milwaukee shoulder (and knee) syndrome
}

\author{
Tânia Santiago, Margarida Coutinho, Armando Malcata, Jose Antonio Pereira da Silva
}

Rheumatology Unit, Centro Hospitalar e Universitário de Coimbra, Portugal

\section{Correspondence to}

Tânia Santiago, tlousasantiago@hotmail.com

Accepted 18 April 2014

\section{DESCRIPTION}

An 80-year-old woman presented with a 1-month history of bilateral shoulder pain and swelling (figure 1). There was no history of any trauma. Physical examination showed limited and painful active and passive range of motion of the shoulders and a valgus deformity of the knees. Anteroposterior X-rays of the shoulders and knees were performed (figure 2). Shoulder ultrasound revealed exuberant subacromial bursitis (figure 3) associated with complete rotator cuff tear bilaterally. Bursa aspiration yielded a haemorrhagic

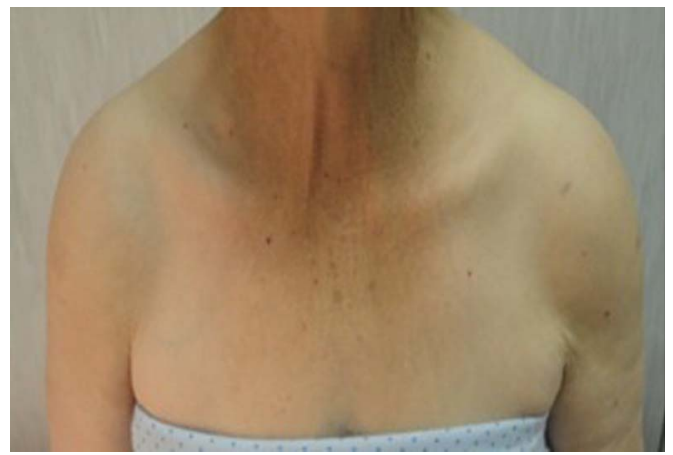

Figure 1 Clinical aspect of the patient. Note the presence of bilateral swelling of the shoulders. non-inflammatory fluid and hydroxyapatite crystals were identified with alizarin red staining (figure 4). Synovial fluid culture was negative. The diagnosis of Milwaukee shoulder syndrome (MSS) was established. The patient was treated with local glucocorticoid injection, with symptomatic benefit.

MSS is a rare destructive shoulder arthropathy characterised by pain, large joint or bursa effusion associated with the deposition of calcium hydroxyapatite crystals. ${ }^{1}$ The condition is characterised by rapid and widespread cartilage and subchondral bone destruction and multiple osteochondral loose bodies. The synovial fluid analysis is the cornerstone of diagnosis, revealing a serohematic synovial fluid and in $80 \%$ of cases with low cellularity $(<2000$ leucocytes $/ \mathrm{mL})$ cells. Typically calcium hydroxyapatite crystals are visualised with alizarin red staining.

Complete rupture of the rotator cuff is commonly seen. ${ }^{2}{ }^{3}$ The knees are affected in $50 \%$ of cases, namely the patellofemoral and lateral tibiofemoral compartments, as opposed to primary osteoarthritis.

Treatment currently is supportive and symptomatic. $^{3}$ Despite the clinical history and radiographic changes suggestive of MSS, the detection and identification of hydroxyapatite crystals in synovial fluid, with alizarin red staining, is critical to confirm the diagnosis of MSS.
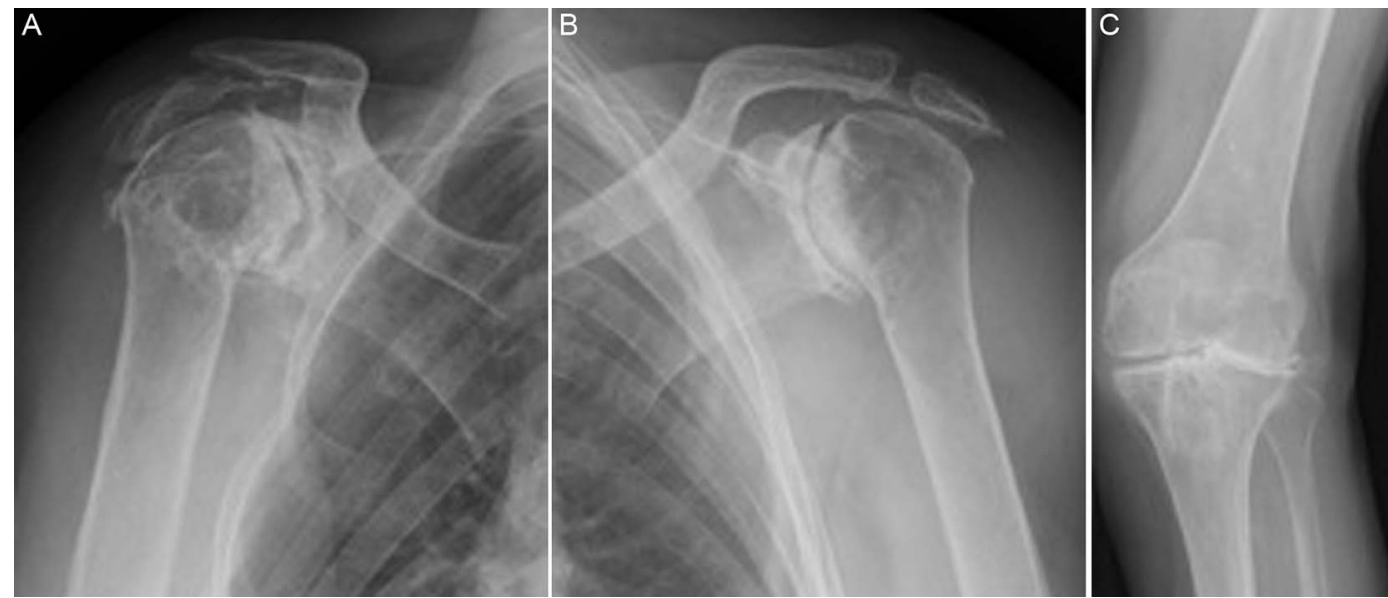

Figure 2 (A) Right shoulder radiograph (anteroposterior, AP): narrowing of the glenohumeral joint, irregular calcifications, sclerosis and osteophytes of the humeral head. (B) Left shoulder radiograph AP: soft tissue swelling, narrowing of the glenohumeral joint space, superior subluxation of the deformed humeral head and soft tissue calcification. (C) Frontal radiograph of the left knee: marked narrowing of the lateral tibiofemoral compartment. 

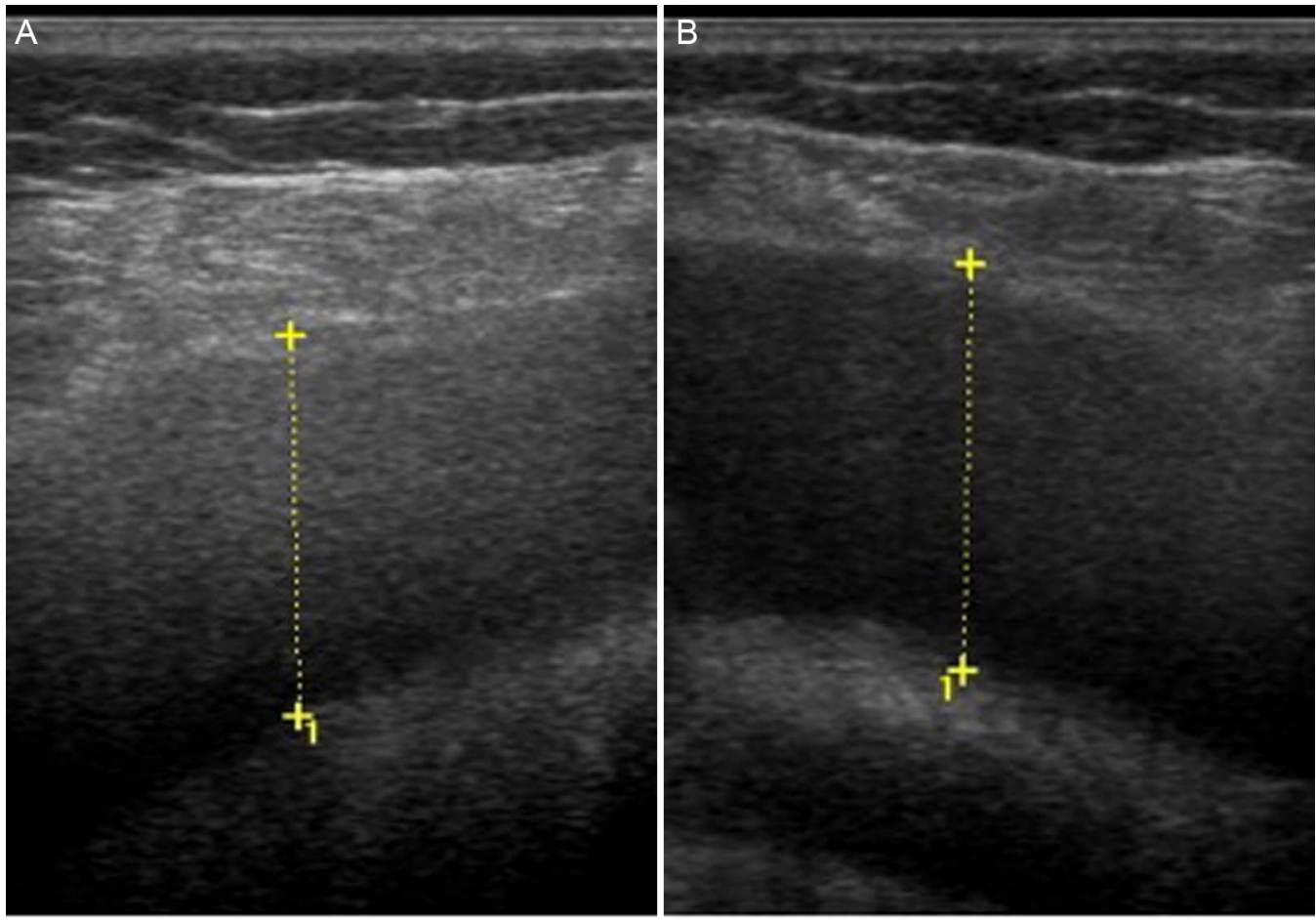

Figure 3 Shoulder ultrasonography (GE Logiq 5 ultrasound machine; 7-12 MHz linear probe; transversal scan): exuberant distension of the subacromial bursa revealed by a hypoechoic image which represents synovial fluid effusion, without power Doppler signal in the synovial membrane. (A) Right shoulder and (B) left shoulder.

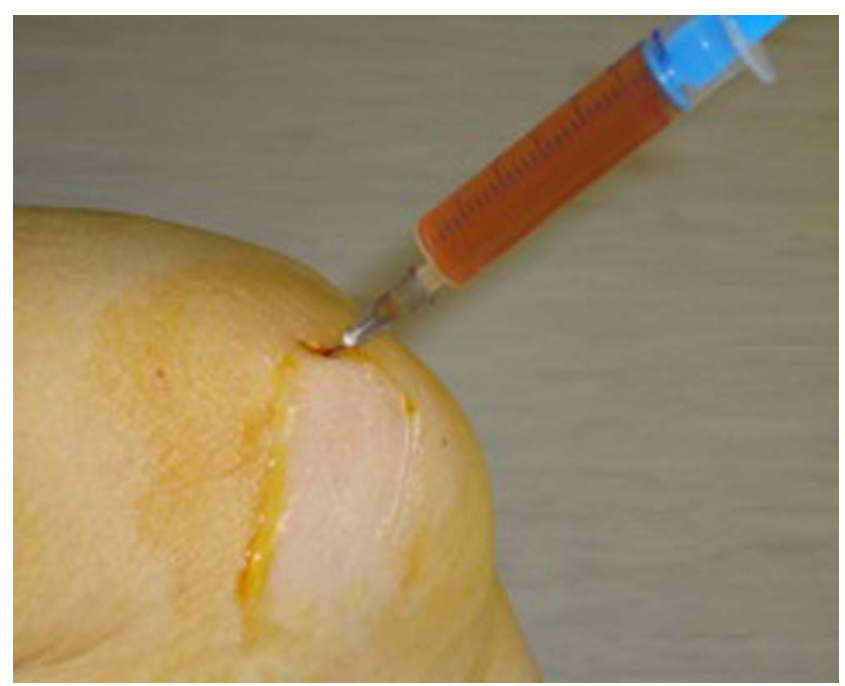

Figure 4 Subacromial bursa aspiration yielded over $200 \mathrm{~mL}$ of a haemorrhagic synovial fluid, which exhibited a non-inflammatory cell count (leucocytes $800 / \mathrm{mm}^{3}$ ).

\section{Learning points}

- Milwaukee shoulder syndrome is a rare and destructive form of arthropathy that mainly affects elderly women.

- It is characterised by intra-articular or periarticular hydroxyapatite crystals and rapid destruction of the rotator cuff and the glenohumeral joint.

- In the appropriate clinical setting, alizarin red staining may help confirm Milwaukee syndrome.

Competing interests None.

Patient consent Obtained.

Provenance and peer review Not commissioned; externally peer reviewed.

\section{REFERENCES}

1 Ea HK, Lioté F. Calcium pyrophosphate dihydrate and basic calcium phosphate crystal-induced arthropathies: update on pathogenesis, clinical features, and therapy. Curr Rheumatol Rep 2004;6:221-7.

2 Epis $\mathrm{O}$, Viola E, Bruschi E, et al. Milwaukee shoulder syndrome (apatite associated destructive arthritis): therapeutic aspects. Reumatismo 2005:57:69-77.

3 Rood MJ, Van Laar JM, De Schepper AM, et al. The Milwaukee shoulder/knee syndrome. J Clin Rheumatol 2008;14:249-50. 
Copyright 2014 BMJ Publishing Group. All rights reserved. For permission to reuse any of this content visit http://group.bmj.com/group/rights-licensing/permissions.

BMJ Case Report Fellows may re-use this article for personal use and teaching without any further permission.

Become a Fellow of BMJ Case Reports today and you can:

- Submit as many cases as you like

- Enjoy fast sympathetic peer review and rapid publication of accepted articles

- Access all the published articles

- Re-use any of the published material for personal use and teaching without further permission

For information on Institutional Fellowships contact consortiasales@bmjgroup.com

Visit casereports.bmj.com for more articles like this and to become a Fellow 